University of Nebraska - Lincoln

DigitalCommons@University of Nebraska - Lincoln

Nebraska Cooperative Fish \& Wildlife Research Nebraska Cooperative Fish \& Wildlife Research Unit -- Staff Publications

1997

\title{
Environmental characteristics of black crappie (Pomoxis nigromaculatus) nesting sites in two South Dakota waters
}

\author{
K. L. Pope \\ South Dakota State University, kpope2@unl.edu \\ D. W. Willis \\ South Dakota State University
}

Follow this and additional works at: https://digitalcommons.unl.edu/ncfwrustaff

Part of the Other Environmental Sciences Commons

Pope, K. L. and Willis, D. W., "Environmental characteristics of black crappie (Pomoxis nigromaculatus) nesting sites in two South Dakota waters" (1997). Nebraska Cooperative Fish \& Wildlife Research Unit -Staff Publications. 65.

https://digitalcommons.unl.edu/ncfwrustaff/65

This Article is brought to you for free and open access by the Nebraska Cooperative Fish \& Wildlife Research Unit at DigitalCommons@University of Nebraska - Lincoln. It has been accepted for inclusion in Nebraska Cooperative Fish \& Wildlife Research Unit -- Staff Publications by an authorized administrator of DigitalCommons@University of Nebraska - Lincoln. 


\section{Environmental characteristics of black crappie (Pomoxis nigromaculatus) nesting sites in two South Dakota waters}

Pope KL, Willis DW. Environmental characteristics of black crappie (Pomoxis nigromaculatus) nesting sites in two South Dakota waters. Ecology of Freshwater Fish 1997: 6: 183-189. (C) Munksgaard, 1997

Abstract - A biotelemetry study was undertaken during spring 1995 to identify black crappie (Pomoxis nigromaculatus) nesting sites in two South Dakota water bodies. Individually coded ultrasonic transmitters were implanted into the body cavity of 15 adult male black crappie in each water body prior to spawning. Available habitat characteristics were recorded at 75 randomly selected sites within each water body, and habitat characteristics at nesting sites were recorded for each male black crappie believed to be nesting. Of the habitat characteristics analyzed, only substrate firmness did not differ $(P=0.79)$ between water bodies. In Richmond Lake, black crappie selected nesting sites with live cattails (Typha spp.) that were protected from prevailing south winds. In Brant Lake, black crappie selected nest sites with vegetation (usually woody debris) and silty substrate that had warmer water and were protected from wind and waves. It appeared that black crappie nested in the most protected areas available.

\section{K. L. Pope, D. W. Willis}

Department of Wildlife and Fisheries Sciences, South Dakota State University, Brookings, South Dakota, USA

Key words: environment; black crappie; nesting Kevin L. Pope, Department of Wildlife and Fisheries Sciences, South Dakota State University, Brookings, SD 57007, USA Accepted for publication February 10, 1997

Un resumen en español se incluye detrás del texto principal de este artículo.

\section{Introduction}

Recruitment processes are typically complex in many fish populations (Houde 1989; DeVries \& Stein 1990). Thus, research into such processes often must focus on specific periods and occurrences. Numerous studies have examined recruitment processes of crappies (Pomoxis spp.) (Mitzner 1981, 1984; Gabelhouse 1984; Guy \& Willis 1995b; Pope et al. 1996); however, no study has specifically targeted nest site selection, which is an obvious prerequisite to recruitment. Mitzner (1987, 1991) examined relations between the relative abundance of larval crappies ( $<15$ days old) and the nearby spawning habitat in Rathbun Lake, Iowa. However, caution must be exercised when relating larval catches to nesting areas because larvae can quickly disperse throughout a water body once they leave the nest.

Thus, a biotelemetry study was undertaken during spring 1995 to 1$)$ identify black crappie ( $P$. nigromaculatus) nesting sites in two South Dakota water bodies and 2) compare and contrast nesting site characteristics and habitat availability in the two water bodies. Such knowledge about black crappie nesting sites should help biologists better understand overall recruitment processes. For example, if black crappie nesting habitat is limited in South Dakota natural lakes, then appropriate habitat improvement may provide more consistent recruitment of black crappie.

\section{Study sites}

Richmond Lake

Richmond Lake is a 336-ha impoundment in northeastern South Dakota. The impoundment has a shoreline development index of 5.8, mean depth of $4.6 \mathrm{~m}$, maximum depth of $8.8 \mathrm{~m}$, morphoedaphic index of 71 and does not thermally stratify during the summer. The watershed is primarily agricultural land $-48 \%$ is row crops and $52 \%$ is pasture (Koth 1981). The black crappie population is characterized by high density 
(Guy \& Willis 1993), slow growth (Guy \& Willis 1995a), and consistent recruitment (Guy \& Willis 1995b).

\section{Brant Lake}

Brant Lake is a 405-ha natural lake in eastern South Dakota. The lake has a shoreline development index of 1.2 , mean depth of $3.4 \mathrm{~m}$, maximum depth of $4.3 \mathrm{~m}$, morphoedaphic index of 191 and does not thermally stratify during the summer. The watershed is primarily agricultural land $-93 \%$ is row crops and 7\% is pasture (Koth 1981). The black crappie population is characterized by low density (Guy \& Willis 1993), fast growth (Guy \& Willis 1995a), and inconsistent recruitment [i.e., missing year classes are common (Guy \& Willis 1995b)].

\section{Material and methods}

Due to low visibility $(<0.1 \mathrm{~m})$ in these two water bodies, visual location of nesting black crappies using SCUBA equipment or snorkeling was not possible. Thus, we were forced to rely on biotelemetry to locate black crappie nesting sites. Recent advances in biotelemetry have allowed movement assessments of crappies. Markham et al. (1991) documented white crappie ( $P$. annularis) summer movement patterns and habitat preferences in an Ohio impoundment. Guy et al. (1992) studied movements of adult black crappie in a South Dakota glacial lake, while Guy et al. (1994) determined monthly and diel movements of white crappie in a South Dakota glacial lake.

Prespawn adult black crappie were collected with trap (modified fyke) nets on 29 April 1995 in Richmond Lake and 2-10 May 1995 in Brant Lake. Suspected males were verified by extracting milt. Individually coded ultrasonic transmitters (40-mm length; 8- $\mathrm{mm}$ diameter; weight, $3.0 \mathrm{~g}$ in water; life span, 47 days) were implanted in the body cavity of 15 male black crappie from each water body [mean total length (TL) \pm 1 standard error $(\mathrm{SE})=230 \pm 3 \mathrm{~mm}$ at Richmond Lake; mean $\mathrm{TL} \pm 1 \mathrm{SE}=254 \pm 6 \mathrm{~mm}$ at Brant Lake] using surgical procedures similar to Hart \& Summerfelt (1975). Ultrasonic transmitters were best suited for this study because conductivity typically exceeded $600 \mu \mathrm{S} / \mathrm{cm}$ in both study waters (Winter 1983). Fish were released immediately after surgery. Data were not collected until 7 days after implantation to allow fish to acclimate to transmitters (Guy et al. 1992, 1994). Because location of spawning sites (not fish movement) was our primary interest, fish locations were made weekly (17 May-22 June 1995) during daylight hours. Male black crappie found at the same location for several weeks in a row were considered to be on nests (Guy et al. 1992, 1994).

Water depth (nearest $\mathrm{cm}$ ), surface water temperature $\left({ }^{\circ} \mathrm{C}\right)$, Secchi depth (nearest $\mathrm{cm}$ ), distance to shore (nearest $\mathrm{m}$ ), shore gradient, substrate firmness, maximum fetch (the distance to the farthest shore measured to the nearest $\mathrm{km}$ ), south fetch (the distance to the shore due south measured to the nearest $\mathrm{km}$ ), and total dissolved solids $(\mathrm{g} / \mathrm{l})$ were measured at presumed nest sites on 5-6 June in Richmond Lake and on 9, 13 and 15 June in Brant Lake. Substrate type and vegetation type within $1 \mathrm{~m}$ of the site were subjectively categorized. Substrate type was categorized as silt, sand, gravel, or rock (usually rip-rap). Vegetation type was categorized as no vegetation present, submerged vegetation, live emergent vegetation [always cattails (Typha spp.)], dead emergent vegetation (always cattails) or woody debris. Shore gradient was measured as the drop in elevation (nearest $\mathrm{cm}$ ) over a horizontal distance of $5 \mathrm{~m}$ from shore. Substrate firmness was measured as the distance that a 32 mm-diameter wooden pole sank into the substrate when a $9.3-\mathrm{kg}$ weight was placed on top of it (Mitzner 1987). Maximum and south fetches were determined using a topographical map. South fetch was chosen because the yearly mean wind resultant direction during 1988-1994 in South Dakota was from the south (National Oceanic and Atmospheric Administration data for Sioux Falls, South Dakota).

All of the above variables, except water depth, were also measured at 75 randomly selected sites around the $0.7-\mathrm{m}$ depth contour on each water body. We chose the $0.7-\mathrm{m}$ contour because that was the approximate mean depth of suspected black crappie nests. Because temperature, Secchi depth, and total dissolved solids are affected by time of sampling, a circuit was made around each water body as quickly as possible to measure these three variables. The circuit was started at 1000 and was completed at 1330 on 6 June at Richmond Lake and at 1530 on 13 June at Brant Lake.

Nonparametric statistics were used to analyze data. In particular, we wanted to test 1) our a priori expectation that available habitat differed between systems, and 2) whether or not black crappie selected certain habitat characteristics for nest sites within each system. Our first null hypothesis was that no difference in habitat characteristics from the 75 random sites existed between the impoundment and natural lake. To test this hypothesis, we used the Kolmogorov-Smirnov twosample test to test for differences in the distribution of continuous habitat characteristics and the chi-square test for homogeneity to test for dif- 
ferences in the distribution of categorized habitat characteristics between Richmond and Brant lakes. We also tested windward south fetch (south fetch with observations of zero deleted) because south fetch on a southern shore will be zero regardless of water body shape.

Our second null hypothesis was that habitat characteristics at nesting sites did not differ from those at random sites within each water body. To test this hypothesis, we used the chi-square goodness-of-fit test to assess differences in the distribution of continuous habitat characteristics because of the small sample size for nesting sites. To use the chi-square goodness-of-fit test, we summarized the data for each characteristic based on the distribution of nesting site data and used the percent of random sites within each category to calculate expected nest site frequencies. In some cases, categories were combined to obtain an expected frequency $\geq 1$ as recommended by Cochran (1952, 1954). The chi-square test for homogeneity was

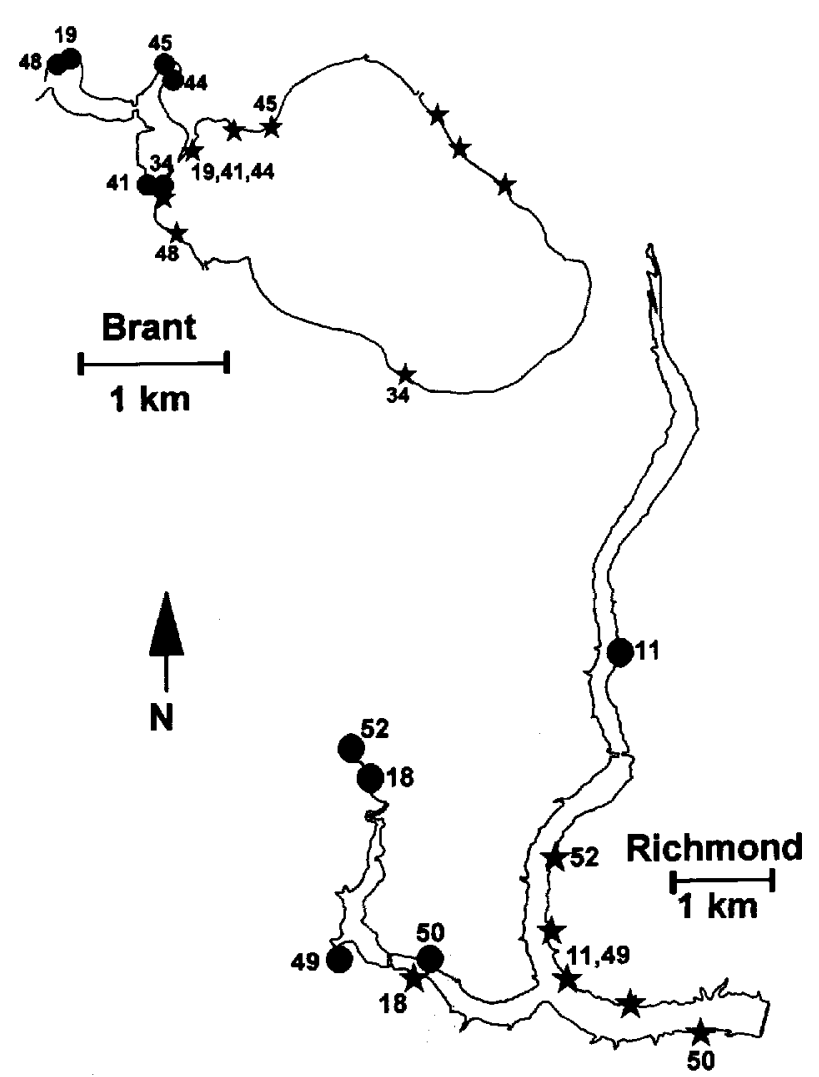

Fig. 1. Maps of Richmond and Brant lakes, South Dakota, showing the capture sites (stars) where 15 male black crappie in each water body were implanted with ultrasonic transmitters and the individual sites (circles) where males nested during the spring 1995. Tag numbers are provided to show movement of males from capture site to presumed nest site (Note: scales for these two water bodies are different; in Richmond Lake, fish 11 and 49 were captured at the same site; in Brant Lake, fish 19, 41 , and 44 were captured at the same site).
Table 1. Statistical comparisons of the distribution of continuous (Kolmogorov-Smirnov test) and categorized (chi-square test for homogeneity) habitat characteristics (see text for a description of each characteristic) at randomly selected sites between Brant and Richmond lakes collected during June 1995. The asymptotic Kolmogorov-Smirnov statistic (KSa) or chi-square statistic $\left(\chi^{2}\right)$ with degrees of freedom (df), and the probability $(P)$ of observing a larger test statistic are provided. The distributions being tested are presented in Fig. 2.

\begin{tabular}{|c|c|c|c|c|c|}
\hline Characteristic & KSa & $P$ & $x^{2}$ & $d f$ & $P$ \\
\hline Surface temperature & 5.2256 & 0.0001 & & & \\
\hline Total dissolved solids & 4.7357 & 0.0001 & & & \\
\hline Maximum fetch & 3.3476 & 0.0001 & & & \\
\hline Secchi depth & 2.4495 & 0.0001 & & & \\
\hline Vegetation type & & & 21.304 & 4 & 0.0003 \\
\hline Substrate type & & & 14.568 & 3 & 0.0022 \\
\hline Windward south fetch ${ }^{a}$ & 1.7545 & 0.0042 & & & \\
\hline Distance to shore & 1.3880 & 0.0424 & & & \\
\hline South fetch & 1.3064 & 0.0659 & & & \\
\hline Shore gradient & 1.2247 & 0.0996 & & & \\
\hline Substrate firmness & 0.6532 & 0.7870 & & & \\
\hline
\end{tabular}

a Testing of the south fetch distribution for sites on northern shores (i.e., sites with no south fetch were deleted for this test).

also used to test for differences in the distribution of substrate and vegetation characteristics between nesting and random sites within Richmond and Brant lakes.

\section{Results}

Fish locations

During tracking, we located six male black crappie in Richmond Lake and nine in Brant Lake. However, based on weekly locations and movement by some individuals during tracking, we believe that only five of those locations in Richmond Lake and six of those locations in Brant Lake were actually nesting sites (Fig. 1). The 11 male black crappie that we believed to have nested did so $0.4-6.0 \mathrm{~km}$ from their site of capture and transmitter implantation (Fig. 1). Despite the fact that we could not verify nests by SCUBA diving or snorkeling, we established each fish location within $1 \mathrm{~m}$ or less. Each nesting location was often near one particular physical feature and males remained there for several weeks. The depth at nesting sites for black crappie ranged from $0.4-0.8 \mathrm{~m}$ in both water bodies.

\section{Habitat characteristics}

Of all habitat characteristics analyzed, only substrate firmness did not differ $(P=0.79)$ between water bodies (Table 1). In Richmond Lake as compared to Brant Lake, water temperatures were warmer, Secchi depths were greater, total dissolved solids were lower, vegetation was more abundant, 

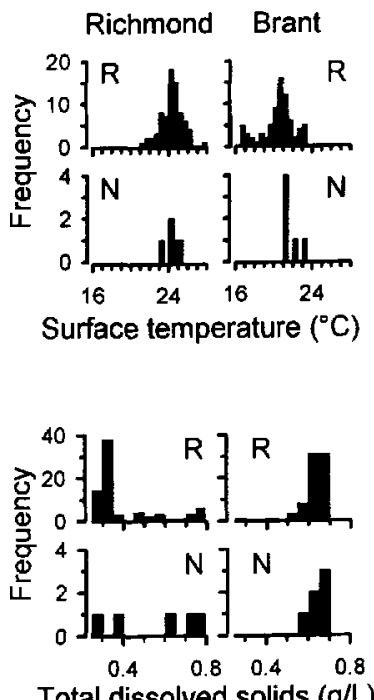

Total dissolved solids $(\mathrm{g} / \mathrm{L})$

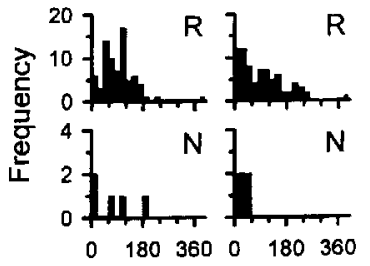

Shore gradient (cm per $5 \mathrm{~m}$ )
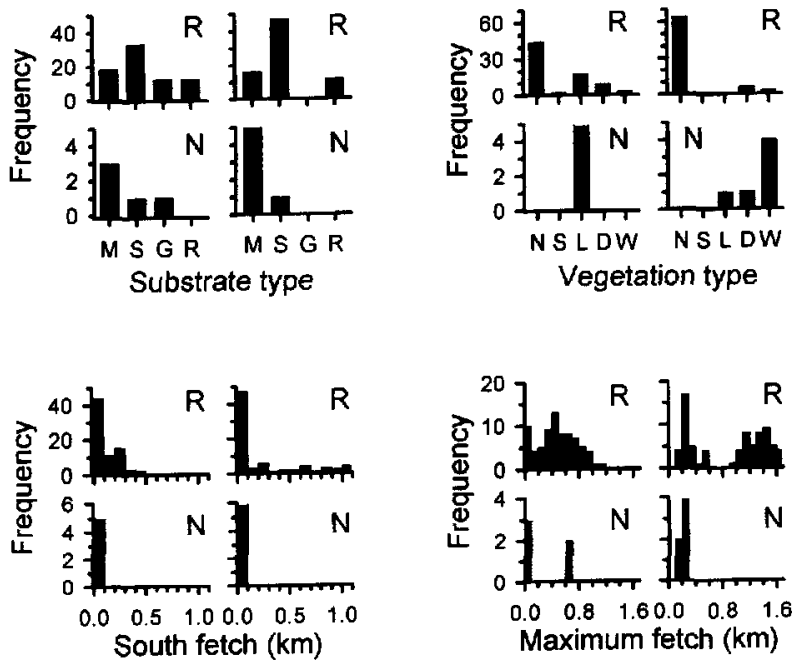

Fig. 2. Frequency histograms depicting surface temperature $\left({ }^{\circ} \mathrm{C}\right)$, Secchi depth $(\mathrm{cm})$, total dissolved solids $(\mathrm{g} / 1)$, distance to shore $(\mathrm{m})$, shore gradient [measured as the drop in elevation (cm) over $5 \mathrm{~m}$ ], substrate firmness [measured as the distance (cm) that a $32-\mathrm{mm}$ diameter wooden pole sank into the substrate when a $9.3-\mathrm{kg}$ weight was placed on top of it], substrate type, vegetation type, south fetch $(\mathrm{km})$, and maximum fetch $(\mathrm{km})$ for 75 random sites $(\mathbf{R})$ and presumed black crappie nest sites (N) during June 1995 in Richmond and Brant lakes, South Dakota. Abbreviations for substrate type are: silt (M), sand (S), gravel $(G)$, and rock ( $R$ ). Abbreviations for vegetation type are: none $(\mathrm{N})$, submerged (S), live emergent (L), dead emergent (D), and woody debris (W). and maximum and south fetches were less (Fig. 2).

\section{Nest characteristics}

In Richmond Lake, $80 \%$ of the black crappie nests were in the west arm of the impoundment (Fig. 1). Two nesting sites in the west arm were located in the extreme upper end of the arm, while no nesting sites were observed in the upper end of the north arm (Fig. 1). The difference in the number of nesting sites in each arm may be a function of habitat. A well-defined creek channel with expanses of cattail growth off either side was present in the west arm, while the north arm was characterized by more extensive cattail stands with no defined creek channel. In addition, $60 \%$ of the black crappie nest sites were located in the middle of the cattail stands, not near the edge where we expected to find them. Nests were often so far back in the cattails that we had to be within $10 \mathrm{~m}$ of some fish to even receive a faint signal from their transmitters.

In Brant Lake, all black crappie nest sites were located in the west bay (Fig. 1). We observed that $67 \%$ of the black crappie nests were under fallen trees, usually located near (within $3 \mathrm{~m}$ ) cattail stands. We found only one nest in the middle of a cattail stand; cattails were much less common in Brant Lake than in Richmond Lake (Fig. 2).

In Richmond Lake, most habitat characteristics at black crappie nest sites were similar to the available habitat characteristics of the impoundment (Table 2, Fig. 2). Only vegetation type and south fetch at nest sites were not used in proportion to their availability (Table 2). Black crappie selected nesting sites with live cattails that were protected

Table 2. Statistical comparisons of habitat characteristics (see text for a description of each characteristic) between presumed black crappie nest sites and random sites in Richmond Lake sampled during June 1995. The chisquare statistic $\left(\chi^{2}\right)$, degrees of freedom (df), the probability $(P)$ of observing a larger test statistic, and the categories used to test are provided. The distributions being tested are presented in Fig. 2 .

\begin{tabular}{lcccc}
\hline Characteristic & $\chi^{2}$ & df & $P$ & Categories \\
\hline Vegetation type & 17.1239 & 4 & 0.0018 & $\begin{array}{c}\text { None, submerged, live } \\
\text { emergent, dead } \\
\text { emergent, woody debris }\end{array}$ \\
South fetch & 3.5324 & 1 & 0.0602 & $<0.1, \geq 0.1$ \\
Total dissolved solids & 2.8568 & 1 & 0.0910 & $<0.4, \geq 0.4$ \\
Substrate type & 4.2045 & 3 & 0.2402 & Silt, sand, gravel, rock ${ }^{\mathrm{a}}$ \\
Secchi depth & 1.1688 & 1 & 0.2796 & $<60, \geq 60$ \\
Substrate firmness & 1.0908 & 1 & 0.2963 & $<10, \geq 10$ \\
Distance to shore & 0.3608 & 1 & 0.5481 & $<5, \geq 5$ \\
Surface temperature & 0.2645 & 1 & 0.6070 & $<24, \geq 24$ \\
Shore gradient & 0.5492 & 2 & 0.7599 & $<80,80-119.9, \geq 120$ \\
Maximum fetch & 0.0588 & 1 & 0.8084 & $<0.5, \geq 0.5$ \\
\hline
\end{tabular}

a These categories were chosen a priori. 
Table 3. Statistical comparisons of habitat characteristics (see text for a description of each characteristic) between presumed black crappie nest sites and random sites in Brant Lake sampled during June 1995. The chi-square statistic $\left(\chi^{2}\right)$, degrees of freedom (df), the probability $(P)$ of observing a larger test statistic, and the categories used to test are provided. The distributions being tested are presented in Fig. 2

\begin{tabular}{lrccc}
\hline Characteristic & \multicolumn{1}{c}{$\chi^{2}$} & df & $P$ & Categories \\
\hline Vegetation type & 72.2500 & 4 & 0.0000 & $\begin{array}{c}\text { None, submerged, live } \\
\text { emergent, dead } \\
\text { emergent, woody debris }\end{array}$ \\
Substrate type & 10.7661 & 2 & 0.0046 & $\begin{array}{c}\text { Silt, sand, rock } \\
\text { Distance to shore }\end{array}$ \\
Maximum fetch & 8.1054 & 1 & 0.0025 & $<10, \geq 10$ \\
Shore gradient & 8.0625 & 1 & 0.0035 & $<0.6, \geq 0.6$ \\
Substrate firmness & 10.7661 & 2 & 0.0045 & $<60, \geq 60$ \\
Surface temperature & 9.6566 & 2 & 0.0080 & $<10,10-19.9, \geq 20$ \\
South fetch & 3.5745 & 1 & 0.0587 & $<0.1, \geq 0.1$ \\
Secchi depth & 3.0659 & 2 & 0.2159 & $<30,30-49.9, \geq 50$ \\
Total dissolved solids & 0.0019 & 1 & 0.9656 & $<0.6, \geq 0.6$ \\
\hline
\end{tabular}

a These categories were chosen a priori.

from prevailing south winds in Richmond Lake (Fig. 2).

In Brant Lake, only total dissolved solids and Secchi depth at black crappie nesting sites were similar to the available habitat characteristics of the natural lake (Table 3, Fig. 2). Vegetation type, substrate type, distance to shore, maximum fetch, shore gradient, substrate firmness, surface temperature, and south fetch at nesting sites were not used in proportion to their availability (Table 3 ). Black crappie selected nest sites with vegetation (usually woody debris) and silt substrate in locations with warmer water that were protected from winds in Brant Lake (Fig. 2).

\section{Discussion}

Although we were unable to verify nests, we do not believe that weekly locations of males at the same site were dead males or deposited transmitters. Based on earlier ultrasonic telemetry studies of crappies (Guy et al. 1992, 1994), we expected a high $(>90 \%)$ percentage of fish to survive the implantation process. We also believe that locating only a portion $(50 \%)$ of fish with transmitters was a function of signal strength reduction caused by vegetation, especially in Richmond Lake. We believe that the dense cover selected by male black crappie for nesting made it difficult to locate these fish. Often, we had to be within $10 \mathrm{~m}$ of presumed nest locations to receive a signal from the transmitter, while we could receive a signal from a fish in open water at distances up to $1000 \mathrm{~m}$. We expended over 700 worker hours searching for nests in these two water bodies. By the time nesting was completed by the males, many transmitters had expired and these fish could not subsequently be located when they moved back into open water.

Our a priori belief that habitat differed between Richmond and Brant lakes was correct. Of the habitat characteristics that were analyzed, only substrate firmness did not differ between impoundment and natural lake. Brant Lake was sampled one week later than Richmond Lake and is located approximately $160 \mathrm{~km}$ south of Richmond Lake; thus, the difference in surface temperatures between the two water bodies, with Brant Lake being cooler than Richmond Lake, was unexpected. The difference in water clarity (measured by Secchi depth), with Richmond Lake being clearer, was primarily a function of biological (algal) turbidity in Brant Lake; however, both water bodies were affected by physical turbidity as well. The difference in maximum and windward south fetches between Richmond and Brant lakes was a function of lake morphometry (i.e., Brant Lake is a natural lake with a low shoreline development index, whereas Richmond Lake is an irregularly shaped impoundment with a high shoreline development index). Richmond Lake offers more areas protected from wind and wave action, which is likely the reason that Richmond Lake had more vegetation than Brant Lake.

Black crappie selected areas with live cattails that were at least partially protected from south winds to build their nests in Richmond Lake. Otherwise, they appeared to use the other habitat characteristics for nesting in proportion to their occurrence in the impoundment. In contrast, black crappie in Brant Lake used areas with structure (woody debris and cattails) and silt substrate that were well protected from wind and wave action and had warmer water temperatures than the main lake for nesting. It is difficult to tell which of these habitat characteristics the black crappie actually selected because measured habitat characteristics were correlated (Pope 1996). Although we determined correlation between habitat characteristics and black crappie nest sites rather than the habitat characteristics that the black crappie actually selected, we speculate that the males selected nesting areas that were protected from wind and wave action and that also offered some type of structure for additional protection of their nest. If our speculation is correct, then the black crappie nested in warmer waters with silt substrate because that was the area that offered protection from wind and waves. Following this logic, male black crappie then neither avoided silt that could smother their eggs nor selected warmer water that would increase the rate of egg development. 
When comparing black crappie nesting sites between water bodies (a comparison that could not be made statistically because available habitat differed between the two water types), black crappie in both water bodies nested in areas that were more protected than expected based on our a priori beliefs. In Richmond Lake, black crappie nests were located in the middle of dense cattail stands at the upper end of the impoundment. In addition, we were surprised at the distance the males traveled to nest in Richmond Lake. We initially expected these black crappie to nest in the vicinity of their capture sites because we thought that the woody debris (e.g., fallen trees) found in the small coves of the lower impoundment would provide sufficient protection from wind and waves. We also thought that moving to another area might be counter productive, as the males in this crowded population would encounter additional black crappie trying to nest. As we expected, black crappie in Brant Lake nested in the northwest bay that provided the only protection from wind and waves.

Mitzner $(1987,1991)$ examined relations between catch rates of larval crappies $(<15 \mathrm{~d}$ old $)$ and nearby available spawning habitat (i.e., water temperature, Secchi depth, substrate firmness, and wind speed and direction) in Rathbun Lake (a 4452-ha impoundment), Iowa. He found that water temperature was important in establishing the threshold of spawning activity, turbidity adversely affected the abundance of larval crappies, highest relative abundance of larval crappies was associated with moderate substrate firmness, and wind action and larval crappies abundance were not significantly $(P>0.05)$ related. In contrast, water temperature was not related to black crappie nest site selection in Richmond Lake; however, it was related to black crappie nest site selection in Brant Lake. Turbidity did not influence black crappie nesting site selection in Richmond or Brant lakes. In Richmond Lake, substrate type and firmness were not related to black crappie nesting site selection, whereas black crappie selected softer substrate (i.e., silt) in Brant Lake. Black crappie in both Richmond and Brant lakes selected areas for nesting that were protected from prevailing south winds.

\section{Conclusion}

Black crappie in these two South Dakota water bodies appeared to nest in the most protected areas available. Thus, protection from wind and wave turbulence seems important for black crappie when selecting spawning areas in South Dakota waters. Furthermore, limited areas providing protection from wind and wave turbulence in Brant
Lake might contribute to the pattern of inconsistent recruitment historically exhibited by black crappie in this water body. Guy \& Willis (1995b) found that black crappie recruitment was more consistent in South Dakota impoundments than in South Dakota natural lakes. Although black crappie selected the most protected areas available in the natural lake (Brant Lake), they did not have access to areas as protected as the nesting sites in the impoundment (Richmond Lake). These protected areas in Brant Lake may not offer sufficient protection from wind and waves during some years. Habitat alterations such as the addition of tree reefs may provide additional protection in Brant Lake; however, substantial habitat alterations would be needed to provide protection anywhere near that available in Richmond Lake.

This study represents the first effort at specifically locating black crappie nesting sites with biotelemetry and provides some new insights into the importance of protection from wind and wave turbulence for black crappie spawning areas. However, this study was limited by low sample size and the inability to visually verify nests. Future research is needed to obtain a larger sample size (both numbers of individual fish and number of water bodies). We suggest that a useful study would involve radio telemetry in water bodies with low water conductivity. Radio signals are much easier to receive than ultrasonic signals in areas with dense vegetation (Winter 1983). In Richmond Lake, we had great difficulty locating black crappie in dense cattail stands and spent much time searching for fish in these areas; however, we were unable to thoroughly search all extensive cattail stands and believe that these are areas where we missed fish (our ultrasonic transmitters worked well in open water). Additionally, radio transmitters are much smaller and should provide much longer battery lives for transmitters equal in size to the ones used in this study.

\section{Resumen}

1. Con el fin de determinar los lugares de nidificación de Poxomis nigromaculatus en dos lagos de Dakota del Sur, llevamos a cabo un estudio de biotelemetría durante la primavera de 1995. Transmisores ultrasónicos codificados individualmente fueron implantados en la cavidad peritoneal de 15 machos adultos antes del desove.

2. Estudiamos las características del hábitat disponible en 75 zonas elegidas al azar en cada uno de los lagos, y lo mismo se hizo con las características de los lugares de nidificación de cada macho adulto que, supuestamente, se encontraba construyendo el nido. De todas las características analizadas, sólo la firmeza del substrato no fue distinta entre los cuerpos de agua. 3. En el Lago Richmond, $P$. nigromaculatus seleccionó aquellos lugares con espadaña (Typha spp.) protegidos de los vientos del sur. En el Lago Brant, la especie seleccionó las zonas con vegetación (generalmente restos de madera) y substrato fangoso 
donde el agua era más templada y al abrigo del viento y las olas. Parece que la especie nidifica en las áreas más protegidas disponibles.

\section{Acknowledgements}

Critical review of this manuscript was provided by Michael Allen, Michael Brown, Dennis DeVries and Christopher Guy. Statistical advice was provided by Robert Lacher. We thank the following for their help in the field and laboratory: Doug Dieterman, Ryan Doorenbos, Doug Franke, Shannon Fisher, Wade Geraets, Keith Hurley, Judy Pope, Norman Pope, Susan Pope, Shane Rustin and Brian Van Zee. This work was funded in part by Federal Aid in Sport Fish Restoration Project F15-R, Study 1552, Job 1, administered by the South Dakota Department of Game, Fish and Parks. This manuscript was approved for publication by the South Dakota Agricultural Experiment Station as Journal Series Number 2908.

\section{References}

DeVries, D.R. and Stein, R.A. 1990. Manipulating shad to enhance sport fisheries in North America: an assessment. North American Journal of Fisheries Management 10: 209223.

Cochran, W.G. 1952. The $\chi^{2}$ test of goodness of fit. Annals of Mathematical Statistics 23: 315-345.

Cochran, W.G. 1954. Some methods for strengthening the common $\chi^{2}$ tests. Biometrics 10: 417-451.

Gabelhouse, D.W., Jr. 1984. An assessment of crappie stocks in small midwestern private impoundments. North American Journal of Fisheries Management 4: 371-384.

Guy, C.S., Neumann, R.M. \& Willis, D.W. 1992. Movement patterns of adult black crappie, Pomoxis nigromaculatus, in Brant Lake, South Dakota. Journal of Freshwater Ecology 7: $137-147$.

Guy, C.S. \& Willis, D.W. 1993. Statewide summary of sampling data for black and white crappies collected from South Dakota waters. South Dakota Department of Game, Fish and Parks, Fisheries Completion Report 93-12, Pierre.

Guy, C.S. \& Willis, D.W. 1995a. Growth of crappies in South Dakota waters. Journal of Freshwater Ecology 10: 151161.
Guy, C.S. \& Willis, D.W. 1995b. Population characteristics of black crappies in South Dakota waters: a case for ecosystemspecific management. North American Journal of Fisheries Management 15: 754-765.

Guy, C.S., Willis, D.W. \& Jackson, J.J. 1994. Biotelemetry of white crappies in a South Dakota glacial lake. Transactions of the American Fisheries Society 123: 63-70.

Hart, L.C. \& Summerfelt, R.C. 1975. Surgical procedures for implanting ultrasonic transmitters into flathead catfish $(P y l o-$ dictis olivaris). Transactions of the American Fisheries Society 104: 56-59.

Houde, E.D. 1989. Subtleties and episodes in the early life of fishes. Journal of Fish Biology 35 (Supplement A): 29-38.

Koth, R.M. 1981. South Dakota lakes classification and inventory. South Dakota Department of Water and Natural Resources, Final Report, Pierre.

Markham, J.L., Johnson, D.L. \& Petering, R.W. 1991. White crappie summer movements and habitat use in a Delaware Reservoir, Ohio. North American Journal of Fisheries Management 11: 504-512.

Mitzner, L.R. 1981. Influence of floodwater storage on abundance of juvenile crappie and subsequent harvest at lake Rathbun, Iowa. North American Journal of Fisheries Management 1: 46-50.

Mitzner, L.R. 1984. Crappie management: problems and solutions. North American Journal of Fisheries Management 4: 339-340.

Mitzner, L.R. 1987. Classification of crappie spawning habitat in Rathbun Lake, Iowa with reference to temperature, turbidity, substrate and wind. Iowa Department of Natural Resources, Technical Bulletin Number 1, Des Moines.

Mitzner, L.R. 1991. Effect of environmental variables upon crappie young, year-class strength, and the sport fishery. North American Journal of Fisheries Management 11: 534 542.

Pope, K.L. 1996. Factors affecting recruitment of black crappies in South Dakota waters. Doctoral dissertation. South Dakota State University, Brookings.

Pope, K.L., Willis, D.W. \& Lucchesi, D.O. 1996. Differential relations of age-0 black crappie and yellow perch to climatological variables in a natural lake. Journal of Freshwater Ecology 11: 345-350.

Winter, J.D. 1983. Underwater biotelemetry. In: Nielsen, L.A. \& Johnson, D.L. ed. Bethesda, MD: Fisheries techniques. American Fisheries Society, pp. 371-395. 